\title{
REPRESENTASI KEMARAHAN TOKOH MINH QUAN DALAM FILM THE FOREIGNER
}

\author{
Skhavito Wicaksono Putra, Anisa Diniati \\ Program Studi Ilmu Komunikasi, Fakultas Industri Kreatif, Institut Teknologi dan Bisnis Kalbis \\ anisa.diniati@kalbis.ac.id
}

Diajukan: 26-08-2019; Direview: 29-08-2019; Diterima: 23-12-2019;

\begin{abstract}
Anger is a negative emotion that humans have. Anger arises due to bad treatment or actions that other people do to someone else. Anger's described in films with different representations. One of the films that represents anger is The Foreigner. The purpose of this study is to look the stages of anger at Minh Quan character in film The Foreigner. This research approach uses a qualitative approach and constructive paradigms, with the content analysis method Triangle Meanings by Charles Sanders Peirce Semiotics (sign, object, interpretant) and the theory istheory of Social Reality Construction in the mass media. This study sees that anger was represented in The Foreigner on Minh Quan character is an example of anger wasn't well controlled. Anger is vented to people who have hurt him through speech, gesture, then carry out acts of aggression in the form of threats, terror bombings and killings.
\end{abstract}

Keywords: anger, film, representation, semiotics

\begin{abstract}
Abstrak
Kemarahan merupakan emosi negatif yang dimiliki manusia. Kemarahan timbul karena perlakuan atau tindakan buruk yang orang lain lakukan kepada seseorang. Kemarahan digambarkan dalam film dengan representasi yang berbeda-beda.Salah satu film yang merepresentasikan kemarahan yaitu The Foreigner. Tujuan penelitian ini untuk melihat tahap kemarahan pada tokoh Minh Quan di film The Foreigner. Pendekatan penelitian ini menggunakan pendekatan kualitatif dan paradigma konstruktivisme, dengan metode analisis isi Segitiga Makna oleh Semiotika Charles Sanders Peirce (sign, object, interpretant) dan teori yang digunakan adalah teori Konstruksi Realitas Sosial di media massa. Hasil penelitian ini menunjukkan bahwa kemarahan yang di representasikan dalam Film The Foreigner pada tokoh Minh Quan merupakan contoh kemarahan yang tidak terkontrol dengan baik. Kemarahan tersebut dilampiaskan kepada orang yang telah menyakitinya melalui cara bicara, gesture tubuh, hingga melakukan tindakan agresi berupa pesan ancaman, terror bomb dan membunuh.
\end{abstract}

Kata kunci: film, kemarahan, representasi, semiotika

\section{PENDAHULUAN}

$\mathrm{M}$ anusia merupakan makhluk yang memiliki emosi. Emosi pada diri manusia dapat berubah tergantung dengan kondisi dan perasaan yang mereka rasakan. Dengan memiliki emosi, manusia dapat mengekespresikan atau mengungkapkan apa yang ada di dalam benak diri mereka. Manusia merupakan makhluk yang emosional disamping sebagai makhluk yang berlogika untuk berpikir, karena manusia adalah makhluk yang memiliki emosi dan rasa.
Oleh karena itu, emosi timbul tergantung dengan perlakuan yang diberikan kepada manusia tersebut.

Emosi positif dapat timbul jika manusia mendapat perlakuan baik atau sedang mengalami hal yang menenangkan dalam hidupnya, sebagai contoh misalnya tertawa; senang; santai; dan lainnya, namun kebalikannya, emosi negatif timbul jika manusia tersebut tidak mendapat perlakuan baik atau kondisi yang tidak menyenangkan, contohnya marah; menangis; takut; dan jengkel (Safaria dan Saputra 2012: 11-13). 
Pada penelitian ini peneliti akan membahas salah satu dari kategori emosi yang disebutkan, yaitu emosi negatif. Salah satu jenis emosi negatif yang sering timbul dan dirasakan setiap orang yaitu marah. Rasa marah tersebut dimiliki setiap orang. Justru tidak normal seandainya ketika hak kita dirampas orang lain, atau kepentingan kita diganggu orang lain dan kita tidak marah. Kemarahan dapat timbul dari diri manusia jika diperlakukan secara tidak baik seperti, disakiti; diskriminasi; diejek; dimusuhi dan lainnya.

Manusia merespon kemarahan yang merek miliki dengan berbeda-beda, ada yang dapat memendam kemarahan tersebut dengan cara berdoa kepada Tuhan atau dengan diam menahan kemarahannya. Pada intensitas yang berlebihan emosi marah dapat menjadi sangat merusak dan berbahaya, contohnya melampiaskannya dengan hasrat untuk melakukan kekerasan, merusak objek sekitar, melukai, bahkan membunuh (Safaria dan Saputra, 2012: 73). Jadi kemarahan pada setiap manusia itu memiliki penyebab tertentu, dan akibat dari kemarahan tersebut akan ditanggapi secara berbeda-beda oleh setiap orang, tergantung bagaimana orang tersebut menyikapinya.

Pada realitasnya, fenomena kemarahan yang berakhir dengan tindak kekerasan hingga pembunuhan sering sekali terjadi. Melalui media massa khususnya film, unsur kemarahan paling sering dimunculkan pada film ber-genre thrill, crime, drama dan action seperti John Wick, The Dark Knight, dan Taken. Pada film tersebut kemarahan umumnya dikaitkan dengan konflik atau persitiwa dari kondisi tidak baik yang dialami oleh tokoh yang diceritakan dan divisualsasikan secara berbeda-beda. Contohnya: kekerasan, mengancam, mengintimidasi melalui perkataan, gesture tubuh. Salah satu film yang terdapat unsur kemarahan adalah The Foreigner, dalam film The Foreigner kemarahan pada tokoh utamanya dimunculkan dengan berbagai tindakan. Mulai dari perkataan, tindakan agresicontohnya: meneror, kekerasan, hingga pada akhirnya harus membunuh.

The Foreigner memilih actor legendaris Jackie Chan dalam memerankan tokoh Minh Quan. The Foreigner adalah sebuah film ber-genre action, thrill yang disutradai oleh Martin Campbell. Film ini merupakan adaptasi dari novel "The Chinaman" yang ditulis oleh Stepen Leather. Pada novel serta film tersebut sama-sama bercerita tentang seorang pria lanjut usia berumur 60 tahun bernama Ngoc Minh Quan atau biasa dipanggil Quan yang dulunya adalah veteran perang di Vietnam, dalam film diceritakan dia adalah seorang ayah yang memiliki satu orang anak perempuan. Quan bekerja di restoran China pribadinya yang bernama "Happy Peacock."

Film ini secara garis besar menceritakan pengalaman buruk yang dialami Minh Quan. Sebelumnya, Minh Quan memiliki seorang istri dan dua orang anak perempuan, namun dia kehilangan kedua putrinya saat berusaha kabur bersama dengan istrinya dari perbatasan Singapura, dua anaknya di culik kemudian dibunuh oleh perompak saat berusaha lari di perbatasan tersebut. Setelah melewati peristiwa itu, Minh Quan harus kehilangan istrinya pada waktu melahirkan putri ketiganya yaitu Fan. Malangnya, Minh Quan juga harus kehilangan putri ketiganya Fan akibat serangan bomb teroris asal Irlandia yang mengatas namakan diri mereka sebagai Authentic IRA (Irish Republican Army) pada sebuah toko di kota london ketika putrinya ingin membeli gaun untuk pesta dikampusnya.

Fan adalah keluarga terakhir yang dimiliki Minh Quan. Karena rasa sayang yang begitu besar terhadapnya, Minh Quan tidak menerima kematian putrinya tersebut secara lapang dada, dalam dirinya dia merasa gagal dalam melaksanakan tugasnya sebagai sosok suami sekaligus seorang ayah. Akibat rasa bersalah, duka, serta kesedihan tersebut merubahnya menjadi kemarahan yang luar biasa, dengan kemarahan yang tidak terpendam lagi Minh Quan melakukan hal terakhir yang dapat dia lakukan sebagai seorang ayah, yaitu mencari keadilan atas kematian Fan dengancara memburu pelaku teroris tersebut.

Peneliti akan menganalisis unsur kemarahan yang direpresentasikan oleh tokoh Minh Quan dalam film The Foreigner dalam mencari keadilan atas kematian puterinya karena aksi bomb teroris. Alasan peneliti tertarik dalam memilih objek penelitian ini karena masih sedikit penelitian yang mengangkat unsur kemarahan pada film layar kaca. Alasan berikutnya adalah konsep, ide, dan 
cerita yang membuat antusias penonton cukup besar untuk mengkonsumsi film The Foreigner, hal ini dapat dilihat berdasarkan penghasilan yang di peroleh film ini.

Berkaitan dengan emosi yang dimiliki oleh karakter dalam sebuah film, Karima \& Christin (2015) menyatakan bahwa pemahaman indeksikalitas dapat memberikan penjelasan sebabakibat yang terjadi pada perilaku individu. Tanda simbol dalam film Little Krishna yang mereka teliti melekat pada tindakan yang diperankan oleh tokoh maupun ekspresi wajah. Hal ini karena sebagian kalangan yakin bahwa komunikasi nonverbal seperti ekspresi, tindakan akan lebih memiliki makna daripada kata-kata. Penggunaan simbol pada film ini digunakan agar dapat mudah dipahami oleh audiens yang menyaksikannya.

Selain film sebagai salah satu wadah adanya realita yang dikonstruksi, dalam jurnal lain yang ditulis oleh Toni \& Rafki (2017:144), bahwa televisi pun dapat digunakan sebagai sebuah media untuk mendapatkan informasi, dimana tokoh yang mereka gambarkan menyaksikan rekonstuksi para pelaku pembunuhan, dan dari situlah ia dapat bertemu dan berkomunikasi langsung dengan para pelaku dan orang-orang yang terlibat dalam pembunuhan saudaranya.

Penelitian terdahulu lainnya yang peneliti gunakan ialah jurnal Ilmiah SCRIPTURA oleh Vidyarini (2007). Penelitian dalam jurnal ini membahas mengenai kecantikan dalam iklan kosmetik The Face Shop yang di representasikan oleh laki-laki di Korea Selatan. Fokus pada penelitian ini ingin menjelaskan bahwa kecantikan kini tidak lagi taboo (tabu) bagi laki-laki. Peneliti berusaha menunjukan jika didalam iklan ini terdapat ideologi kapitalisme, yaitu kecantikan dalam hal perindustrian kecantikan, stigma kecantikan, bahkan laki-laki dijadikan sebagai objek kecantikan tidak lepas dari pengaruh kapitalisme. Kecantikan bukan lagi berupa fisik ideal di mata media dan masyarakat baik itu lakilaki maupun perempuan.Kecantikan yang ideal diwujudkan melalui penggunaan produk-produk kecantikan dalam kasus ini The Face Shop, dengan demikian kecantikan dijadikan sebagai komoditas yang dihasilkan oleh kapitalisme. Persamaan pada penelitian ini adalah menggunakan semiotika sebagai teori dan metode analisisnya, perbedaannya penelitian ini terdapat pada media, topik pembahasan yang diangkat serta analisis yang digunakan adalah semiotika John Fiske.

Dalam film The Foreigner inilah kemarahan di representasikan. Kemarahan yang muncul pada diri Minh Quan tumbuh secara bertahap mulai dari penyebab kemarahan itu, hingga bagaimana Minh Quanmelampiaskan kemarahannya dengan bertindak diluar jalur hukum. Segala bentuk kemarahan pada Minh Quan direpresentasikan menjadi sebuah tanda. Ilmu yang mempelajari tentang tanda adalah semiotika. Semiotika adalah ilmu atau metode analisis untuk mengkaji tanda (Sobur, 2009: 15). Ada banyak jenis semiotika dalam dunia komunikasi, pada penelitian ini peneliti memilih semiotika model Charles Sanders Peirce. Peirce membagi elemen makna menjadi tiga dan menjadikannya sebagai teori segitiga makna (triangle meaning) yang terdiri atas sign (tanda), object (objek), dan interpretant (interpretan). Menurut Peirce, salah satu bentuk tanda adalah kata. Apabila elemen-elemen makna itu berinteraksi dalam benak seseorang, maka munculah makna tentang sesuatu yang diwakili oleh tanda tersebut (Sobur, 2009:114-115).

Teori konstruksi realitas sosial peneliti gunakan dalam penelitian ini dengan tujuan mengamati bagaimana bentuk kemarahan yang di konstruksi pada tokoh Minh Quan kemudian ditampilkan dalam film The Foreigner. Meskipun terdapat beberapa penelitian terdahulu yang menganalisis sebuah film menggunakan tanda-tanda non verbal dalam Semiotika, seperti "Analisis Semiotika Citra Polisi Dalam Film Pendek "Joni Sok Jagoan" Di Youtube (Diniati \& Pratiwi, 2018), peneliti lebih fokus menganalisis representasi makna dari setiap adegan khsusnya proses terbentuknya kemarahan. Sedangkan tanda-tanda non verbal yang dikemukakan oleh Diniati \& Pratiwi (2018), tanda-tanda atau pesan nonverbal yang terdapat dalam setiap adegan.

Kemarahan pada tokoh Minh Quan merupakan refleksi dari keadaan manusia ketika diselimuti oleh kemarahan, lalu bagaimana manusia tersebut merespon kemarahannya dengan tindakan yang berbeda-beda. Berger \& Luckmann (dalam Bungin 2013:193) mengatakan konstruksi realitas 
sosial terjadi melalui tiga proses sosial, yaitu eksternalisasi, objektivasi, inernalisasi. Tiga proses ini terjadi di antara individu satu dengan individu lainnya dalam masyarakat. Dengan menggunakan teori konstruksi realitas sosial melalui tiga tahap pendekatan tersebut, peneliti akan melihat bagaimana representasi kemarahan dari tokoh Minh Quan karena anaknya tewas terbunuh oleh teroris IRA. Sampai dirinya berhasil dalam melampiaskan kemarahannya kepada para pelaku yang bertanggung jawab atas kematian anaknya.

\section{LITERATUR DAN METODOLOGI}

Kemarahan yang direpresentasikan dalam film The Foreigner merupakan representasi kemarahan pada diri manusia di dunia nyata. Kemarahan pada dirimanusia dipacu dengan tindakan, atauperlakuan buruk yang orang lain lakukan terhadap manusia tersebut. Manusia tidak akan menerima jika dirinya mendapat perlakuan buruk dari orang lain dan akan merespon kembali perbuatan orang tersebut dengan cara yang berbeda-beda. Representasi berasal dari bahasa inggris, representation, yang artinya perwakilan, gambaran atau penggambaran. Secara sederhana, representasi dapat diartikan sebagai gambaran mengenai suatu hal yang terdapat dalam kehidupan yang digambarkan melalui suatu media (Vera, 2014: 96).

Representasi kemarahan pada tokoh Minh Quan dalam film The Foreigner memiliki makna yang berbeda di setiap adegannya, dimulai dari penyebab kemarahan itu dapat muncul lalu bagaimana Minh Quan merespon kemarahannya dan melampiaskannya. Dengan menggunakan teori konstruksi realitas sosial peneliti berusaha mengamati bagaimana bentuk kemarahan yang di konstruksi pada tokoh Minh Quan kemudian ditampilkan dalam film The Foreigner. Teori dan pendekatan konstruksi sosial atas realitas terjadi secara simultan melalui tiga proses sosial, yaitu eksternalisasi, obyektivasi dan internalisasi. Tiga proses ini terjadi diantara individu satu dengan individu lainnya dalam masyarakat. (Bungin, 2008: 193).

Frans M. Parera (dalam Bungin, 2013:197) menjelaskan, tugas pokok sosiologi pengetahuan adalah menjelaskan dialektika antara diri (self) dengan dunia sosiokultural. Dialektika ini berlangsung dalam proses dengan tiga momen simultan, diantaranya: (1) Eksternalisasi (penyesuaian diri) dengan dunia sosiokultural sebagai produk manusia; (2) Objektivasi, yaitu interaksi sosial yang terjadi dalam dunia intersubjektif yang dilembagakan atau mengalami proses institusionalisasi; sedangkan (3) Internalisasi, yaitu proses yang mana individu mengindentifikasikan dirinya dengan lembaga-lembaga sosial atau organisasi sosial tempat individu menjadi anggotanya. Tiga momen dialektika itu memunculkan suatu proses konstruksi sosial yang dilihat dari segi asal mulanya merupakan hasil ciptaan manusia, yaitu buatan interaksi intersubjektif (Bungin, 2013: 197198).

Pendekatan dalam penelitian ini menggunakan pendekatan kualitatif dan paradigma konstruktivisme, dengan metode analisis isi Segitiga Makna oleh Semiotika Charles Sanders Peirce (sign, object, dan interpretant). Bahan penelitian yang digunakan pada penelitian ini adalah film The Foreigner dengan mengamati scene yang memiliki unsur kemarahan dari tokoh Minh Quan. Data diperoleh melalui data primer dan data sekunder. Data primer pada penelitian ini diambil dari potongan scene atau adegan pada film The Foreigner yang merepresentasikan kemarahan pada tokoh Minh Quan. Sedangkan data sekunder atau data pendukung didapatkan melalui buku, jurnal, tesis, dan sumber internet.

Penelitian ini menggunakan segitiga makna milik Charles Sanders Peirce, yaitu sign, object, dan interpretant untuk menganalisis data. Menurut Hamad (dalam Sobur, 2009: 114) Semiotik untuk studi media massa ternyata tak hanya terbatas sebagai kerangka teori, namun sekaligus juga bisa sebagai metode analisis. Kita, misalnya, dapat menjadikan teori segi tiga makna (triangle meaning) Peirce yang terdiri atas sign (tanda), object (objek), interpretant.

Dalam memaknai tahapan kemarahan dengan model segitiga makna Peirce, peneliti akan mengamati teknik pengambilan gambar pada film tersebut. Setiap pengambilan gambar dalam sebuah film tentu memiliki pemaknaan yang berbeda. Berikut tabel pemaknaan dalam pengambilan gambar yang akan peneliti gunakan 
dalam mengamati unsur kemarahan melalui scene pada film The Foreigner.

\section{TEMUAN DAN DISKUSI}

The Foreigner merupakan film yang disutradai oleh Martin Campbell, film ini merupakan sebuah adaptasi novel The Chinaman (1992) yang ditulis oleh Stephen Leather dan distribusikan oleh STX Entertainment. Secara garis besar film ini bercerita tentang pengalaman buruk yang dialami oleh Ngoc Minh Quan sebagai pria biasa yang bekerja sebagai pemilik restoran Cina di London dan memiliki satu orang anak perempuan bernama Fan. Suatu ketika musibah menimpa dirinya ketika putrinya tewas terkena serangan bomb di sebuah toko di depan matanya sendiri. Berawal dari kejadian itulah Minh Quan menjadi depresi dalam menahan kesedihan dan kemarahannya tersebut, karena tidak dapat terpendam lalgi Minh Quan berusaha untuk mencari keadilan atas kematian putrinya dengan mencari nama-nama teroris yang telah membunuh putrinya.Minh Quan melakukan berbagai tindakan secara bertahap dalam melampiaskan kemarahannya.Mulai dari meneror, mengancam, bahkan hingga melakukan tindakan agresi seperti kekerasan, mengebomb, dan membunuh. Segala tahap kemarahan yang dilampiaskan oleh Minh Quan hingga dia berhasil mendapat nama-nama teroris tersebut dan kemudian membunuh mereka.

Tabel 1. Penyebab Kemarahan Minh Quan

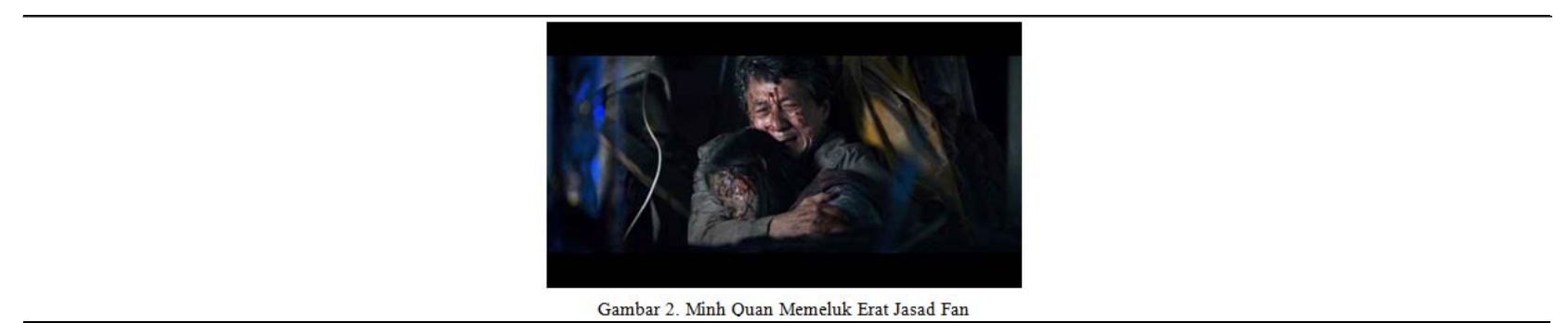

\begin{tabular}{|c|c|}
\hline Object & Interpretant \\
\hline $\begin{array}{l}\text { Gambar } \\
\text { menggambarkan suasana } \\
\text { di malam hari, pada } \\
\text { background terlihat kain } \\
\text { kuning, balok kayu, dan } \\
\text { kabel putih yang } \\
\text { tergantung disebelah } \\
\text { pria dan wanita dalam } \\
\text { gambar. Background } \\
\text { yang di perlihatkan pada } \\
\text { gambar diatas berada } \\
\text { dalam kondisi hancur } \\
\text { berantakan akibat suatu } \\
\text { peristiwa atau insiden. } \\
\text { Disana terlihat sosok } \\
\text { pria dengan mengenakan } \\
\text { pakaian jaket berwarna } \\
\text { abu-abu bersama } \\
\text { seorang wanita berusia } \\
\text { remaja mengenakan } \\
\text { pakaian berupa jaket } \\
\text { hoodie dengan penutup } \\
\text { berwarna maroon, } \\
\text { keduanya terlihat penuh } \\
\text { luka dengan darah dan } \\
\text { beberapa serpihan kaca di } \\
\text { wajahnya. }\end{array}$ & $\begin{array}{l}\text { Quan mengenakan jaket berwarna abu- abu, Menurut Nugroho (2008: 38) secara } \\
\text { makna negatif warna abu-abu menggambarkan kesedihan, emosi kuat, perkabungan. } \\
\text { Dilihat dari scene diatas warna abu-abu tersebut mewakili emosi kesedihan yang } \\
\text { begitu kuat yang di ekspresikan pada Quan ketika memeluk Fan. } \\
\text { Emosi kesedihan bisa disebabkan karena kepedihan ditinggal pergi orang yang } \\
\text { berharga (Fitriyani dan Amda, 2016: 148). Quan terlihat menangis ketika memeluk } \\
\text { Fan yang sudah meninggal. Kesedihan dapat dilihat dari raut wajah yang diperlihatkan } \\
\text { oleh mata yang tidak fokus, sudut bibir yang tertarik ke bawah dan mata yang tidak } \\
\text { fokus (Fitriyani dan Amda, 2016: 148). Wajah yang dipenuhi dengan luka pada Quan } \\
\text { memperlihatkan kesedihannya saat memeluk Fan yang bersandar di bahunya dalam } \\
\text { kondisi terluka dan sudah tidak bernyawa. } \\
\text { Pelukan dapat diartikan sebagai cinta- keintiman, hal ini merujuk pada sentuhan yang } \\
\text { menyatakan keterikatan emosional atau ketertarikan, misalnya mencium pipi orang tua } \\
\text { dengan lembut; orang yang sepenuhnya memeluk orang lain (Mulyana, 2014: 380). } \\
\text { Dalam hal ini Minh Quan mengetahui bahwa Fan sudah tidak bernyawa lagi akibat } \\
\text { ledakan bom yang menimpa diri mereka. } \\
\text { Pelukan tersebut menggambarkan pelukan cinta dari seorang ibu, dimana pelukan cinta } \\
\text { tersebut merupakan jenis cinta tertinggi yang memiliki ikatan emosional paling luhur } \\
\text { (Wisnuwardhani dan Mashoedi, 2012: 72). Mengingat istrinya meninggal saat } \\
\text { melahirkan Fan, Quan memegang dua peranan penting dalam kehidupan Fan, yaitu } \\
\text { sebagai seorang ayah sekaligus ibu dalam merawat Fan dari kecil hingga dirinya } \\
\text { beranjak remaja. Pelukan yang ditunjukan Quan menggambarkan kasih sayang yang } \\
\text { begitu besar dari seorang ayah dan ibu kepada putrinya, serta menggambarkan } \\
\text { kemarahannya karena putrinya tewas dengan cara yang tragis. } \\
\text { Menurut Safaria dan Saputra (2012: 79) rasa marah dalam diri seseorang dapat muncul } \\
\text { ketika haknya oleh dirampas orang lain, atau kepentingan orang tersebut diganggu } \\
\text { oleh orang lain, Fan adalah keluarga terakhir sekaligus orang terpenting bagi Minh } \\
\text { Quan, karena kejadian ini telah merampas nyawa Fan dari hidup Minh Quan, dia tidak } \\
\text { dapat dan menjadikan rasa duka serta kesedihan tersebut menjadi kemarahan. }\end{array}$ \\
\hline
\end{tabular}


Kesimpulan pada scene yang terdapat dalam tabel 1 adalah menggambarkan rasa cinta dan kasih sayang yang begitu besar oleh Minh Quan sebagai seorang ayah sekaligus ibu kepada Fan yang merupakan anak semata wayangnya. Fan adalah satu- satunya keluarga serta orang terpenting yang dia miliki. Kemarahan pada diri manusia muncul di dasari dengan alasan atau penyebab. Karena insiden bom tersebut telah merenggut nyawa Fan dari sisinya, hal inilah yang menjadi pemicu munculnya kemarahan dalam diri Quan kepada pelaku teroris yang bertanggung jawab atas kematian putri yang sangat di cintainya.

Tabel 2. Puncak Kemarahan Minh Quan

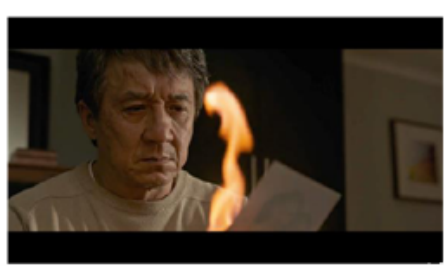

Gambar 12 Ekspresi Kemarahan Quan

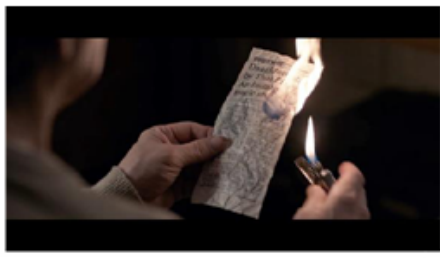

Gambar 14 Quan membakar Koran Berita Kematian Anaknya

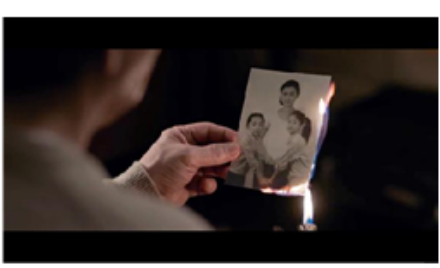

Gambar 13 Quan, Membakar. Foto Anak dan Istrinya

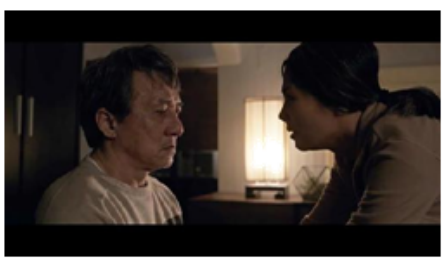

Gambar 15 Lam Menxadarkan Quan

\begin{tabular}{l} 
Object \\
\hline Dari keempat gambar di atas, pria dalam scene \\
mengenakan sebuah sweater berwarna krem \\
dengan motif garis berwarna hijau, dan merah.
\end{tabular}

Pada Gambar 12 menggunakan dengan pengambilan gambar Middle Close Up memperlihatkan seorang pria tua dengan biasan api di depan wajahnya.Pria tersebut sedang membakar sebuah gambar yang terlihat transparan, gambar tersebut merupakan sebuah foto. Pada foto yang sedang terbakar api terlihat siluet gambar kepala seseorang yang terlihat samar-samar. Background pada gambar berada didalam sebuah ruangan dimana terlihat dua buah bingkai lukisan dan lemari hitam dibelakang pria tersebut.

Gambar 13 memperjelas kegiatan yang sedang dilakukan pria tersebut, pada gambar dapat terlihat tangan pria dengan berpakaian sweater berwarna krem sedang membakar sebuah foto bernuansa black and white menggunakan korek gas. Dengan pengambilan gambar Over Shoulder Shoot memperlihatkan orang tersebut sedang membakar foto tiga perempuan yang diantaranya terdapat satu orang wanita dan dua orang anak perempuan yang sedang memeluk wanita dalam foto.

\section{Analisis Gambar 12}

Interpretant
Ekspresi kemarahan dapat dilihat melalui sisi alis bagian dalam yang menyatu dan condong ke bawah, bibir yang menyempir dan pandangan mata yang menajam. Emosi kemarahan timbul karena ketidaksesuaian dengan antara apa yang sudah direncanakan dengan hasil yang dicapai (Fitriyani dan Amda, 2016: 147). Dalam scene terlihat Quan sedang membakar sebuah kertas yang ada dihadapannya. Kemarahan pada dirinya diibaratkan seperti api yang membakar kertas itu. Quan melampiaskan kemarahan dengan menghancurkan objek yang ada disekitarnya. Kemarahannya tidak terbendung lagi karena sikap penolakan yang diberikan Hennessy di telfon sebelumnya.

\section{Analisis Gambar 13}

Kedua putrinya sudah lama meninggal saat Fan belum dilahirkan, sedangkan Istrinya meninggal saat melahirkan Fan. Quan mengingat kini dia tidak punya keluarga lagi dan tidak mau rasa stress dan depresi dalam dirinya mengganggu kehidupannya. Karena itulah dia membakar foto anak dan istrinya tersebut.

\section{Analisis Gambar 14}

Dengan pengambilan Close $U p$ memperlihatkan Quan membakar kertas Koran yang bertuliskan "Daughter slain by Thai Pirates. An Immigrant tragic story." Pada koran tersebut merupakan pemberitaan mengenai kisah keluarganya sebagai imigran dan kedua anak perempuannya yang mati dibunuh oleh bajak laut Thailand. Dengan membakar Koran dan foto tadi adalah upaya Quan dalam melupakan masa lalunya, Kondisi tersebut menyatakan suatu penolakan tapi tidak dapat menolak, 
Pada gambar 14 menggunakan pengambilan gambar yang sama dengan gambar 13 yaitu Over Shoulder Shot. Setelah membakar foto tadi, tangan pria tersebut memegang sebuah potongan lembar koran lalu membakarnya dengan sebuah korek gas.

Pada gambar 15 terlihat pria dan wanita itu sedang berhadapan satu sama lain, si wanita terlihat sedang menatap wajah pria tersebut dengan tatapan sedih, namun pria tersebut terlihat memalingkan matanya dari hadapan si wanita dengan sengaja. Pengambilan gambar pada gambar 15 adalah Close Up. sehingga yang terjadi adalah marah kepada diri sendiri (Eskawati, 2015: 52). Quan tidak dapat menerima kenyataan Fan harus mati akibat kejadian tragis sama seperti almarhumah kedua anak perempuannya. Quan marah kepada dirinya dan menyalahkan dirinya sendiri karena tidak dapat menjaga seluruh keluarganya.Akhirnya dia melampiaskan kemarahannya dengan membakar seluruh ingatan tentang keluarganya.

\section{Analisis Gambar 15}

Lam menatap wajah Quan yang terlihat sangat depresi setelah peristiwa yang menewaskan Fan. Disini Lam berusaha untuk menyadarkan Quan agar tidak terus-terusan berada di dalam kondisi ini.
Representasi kemarahan dalam tabel 2 adalah, dimana perasaan bersalah atau menyalahkan diri sendiri karena tidak bisa melindungi orang yang kita cintai dapat mengakibatkan rasa stress dan depresi. Ketika perasaan tersebut terlalu dipikirkan dan dipendam berlarut-larut akan memicu rasa kemarahan yang tidak dapat terkontrol, sehingga omongan orang lain pun tidak dapat menyadarkan kita. Pada tabel ini Quan dalam mengekspresikan kemarahannya berada di kondisi Anger In. Menurut Spielberger (dalam Safaria dan Saputra, 2015: 85) menyebutkan ada tiga cara bagaimana individu dalam mengekspresikan kemarahannya, yaitu Anger in, Anger Out, dan Anger Control. Anger In adalah dimana seseorang dalam keadaan marah, dirinya lebih memilih diam dan tidak mau menceritakannya kepada siapapun atau tidak mau mendengar orang lain, kondisi sperti ini akan memberi dampak negatif bagi dirinya sendiri. Hal ini dapat dilihat pada diri Quan yang marah dan menyalahkan dirinya sendiri karena tidak bisa melindungi keluarganya. Kemarahan tersebut membutakan isi hatinya, hingga dia tidak mau mendengarkan perkataan Lam yang peduli dengan keadaannya.

Tabel 3. Ancaman Bomb Pertama

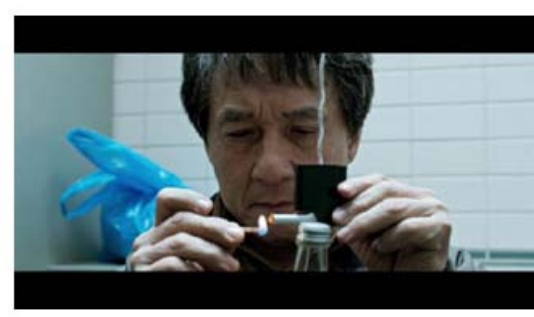

Gambar 19 Quan Merakit Bomb

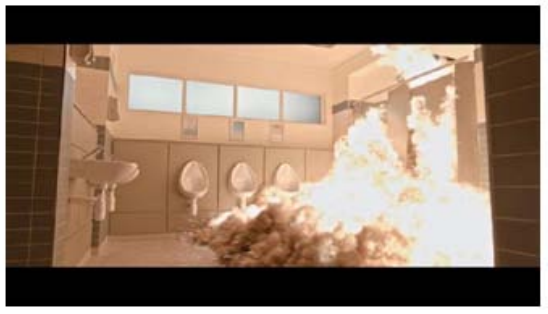

Gambar 20 Ledakan Bom $\mid$

\begin{tabular}{l}
\hline Object \\
\hline Pada gambar 19 menggunakan \\
pengambilan gambar Close Up. \\
Dengan pengambilan gambar \\
tersebut terlihat seorang pria tua \\
sedang memegang sebuah korek \\
api dengan tangan kanannya \\
sementara tangan sebelah kiri pria \\
itu memegang botol kaca yang \\
diikatkan dengan sebuah rokok \\
dan kotak korek api, pria itu \\
terlihat ingin membakar rokok \\
yang digantungkan bersama botol \\
dan korek. Latar yang terlihat \\
pada scene berupa dinding
\end{tabular}

\section{Analisis Gambar 19}

Situasi yang bisa membuat orang menjadi sangat marah antara lain dipaksa untuk melakukan sesuatu, maupun frustasi secara fisik maupun psikologis (Amda dan Fitriyani 2016:147). Pada scene sbeleumnya dia mengatakan "You will change your mind" yang artinya "Kau akan merubah pikiranmu" kepada Hennessy. Perkataan tersebut merupakan ancaman awal dimana kemarahannya berubah menjadi tindak agresi karena Hennessy menolak untuk membantunya. Quan ingin membuktikan jika perkataannya tidak main-main. Menurut Dyer (dalam Safaria dan Saputra, 2012: 95) mendefinisikan marah atau kemarahan sebagai suatu reaksi terhadap frustasi yang terlatih dimana seseorang berbuat dengan caracara yang sesungguhnya ia tidak menginginkannya. Pelampiasan dari kemarahan dalam dirinya pun akhirnya terjadi.

Analisis Gambar 20

Tindakan bomb ini merupakan ancaman yang dilakukan Quan sebagai tindakan 
keramik dengan motif bata berwarna putih dan sebuah plastik biru di belakang pria itu.

Dengan pengambilan Estabiling Shot di gambar 20 terlihat setting latar toilet pria yang berada dalam keadaan kosong, di toilet itu terdapat dua wastafel dan tiga saluran untuk buang air kecil berwarna putih, kemudian muncul ledakan besar yang keluar dari arah pintu toilet itu. agresi emosional, agresi emosional terjadi jika tujuan yang diharapkan terhalang kemudian menimbulkan dorongan kearah agresi emosional, dimana kecenderungan untuk menyakiti orang dengan tujuan utama memberikan rasa sakit itu sendiri (Berkowitz, 2006: 43). Aksi bomb tersebut dia lakukan agar Hennessy juga merasakan rasa sakit yang dia rasakan ketika putrinya tewas karena ledakan bomb. Quan memilih tindak bomb dalam meluapkan kemarahannya, hal ini merupakan balas dendam kematian putrinya. Menurut (Berkowitz, 2006:186) balas dendam adalah jenis aksi kemarahan yang biasanya dilakukan setelah melakukan refleksi terhadap rasa sakit hati atas serangan orang lain. Meskipun tindak agresi ini bersifat destruktif, Quan tetap melihat situasi dan kondisi jika tindakannya itu tidak melukai atau merenggut nyawa orang lain. Maka dari itu, Quan memilih toilet pria yang berada dalam keadaan kosong.
Pada tabel 3 Quan berada dalam kondisi Anger Out. Menurut Speilberger (Safaria dan Saputra, 2012:86), kondisi Anger out adalah dimana individu mengekspresikan emosi kemarahannya dengan tindakan dalam bentuk agresif dan merusak. Akibat rasa tidak puas dengan jawaban Hennessy, kemarahan dalam diri Quan meledak dan berubah menjadi tindak agresi, Quan memilih balas dendam dengan melakukan ancaman bomb kepada
Hennessy. Hal ini dia lakukan agar Hennessy juga merasakan dirinya harus kehilangan putrinya karena ledakan bomb. Namun dalam melampiaskan agresi dari kemarahannya Quan tetap memperhatikan situasi dimana dia memastikan jika aksinya tidak melukai atau merenggut nyawa orang lain. Yang artinya, ancaman bomb itu hanya berupa ancaman kepada Hennessy.

Tabel 4. Pesan Ancaman Quan

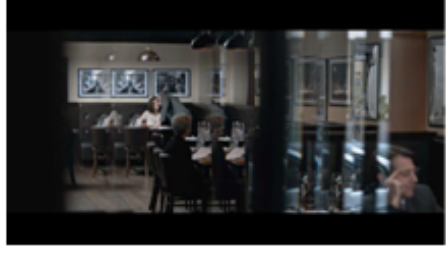

Gambar 21 Hennessy Menemui Maggie

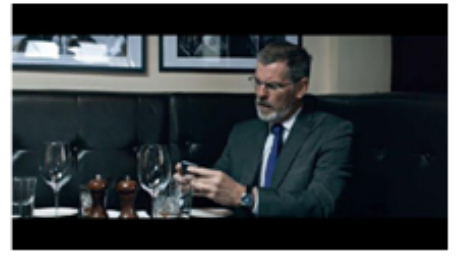

Gambar 22 Hennessy Terkejut

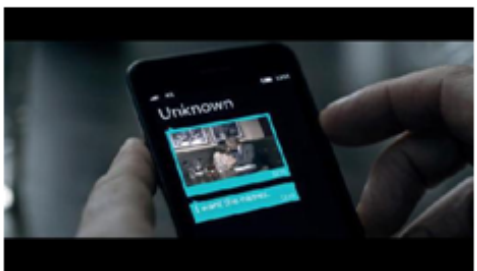

Gambar 23 Pesan Ancaman Quan

\section{Object}

Gambar 21 menggunakan pengambilan Long Shot, dimana pada scene diatas menunjukan setting disebuah restoran yang terlihat fancy. Ada tiga lukisan dan empat orang yang terlihat di dalam restoran itu, dua diantaranya adalah seorang wanita muda menggunakan pakaian blazer perempuan berwarna putih yang sedang duduk, satu orang lagi adalah pria tua dengan jas berwarna abuabu sedang mencium wanita itu. View Point dalam melihat setting restoran pada scene diatasadalah sudut pandang orang ketiga dengan posisi berada di luar jendela restoran. Pandangan orang tersebut sedang

\section{Analisis Gambar 21}

Hennessy menggunakan pakaian berwarna abu-abu yang memiliki makna positif yaitu formalitas, sedangkan Maggie menggunakan pakaian berwarna putih yang bermakna positif kepolosan, dan suci (Nugroho, 2008: 38). Pengambilan gambar Long Shot dengan view point dari luar kaca, merupakan sudut pandang Quan yang menlihat ke dalam restoran. Dalam komunikasi nonverbal ciuman merupakan salah satu bentuk dari komunikasi berupa sentuhan keintiman secara fisik yang merujuk kepada 
melihat keaarah wanita dan pria yang sedang bermesraan di dalam restoran itu.

Gambar 22 menunjukan seorang pria tua sedang duduk di sofa berwarna hitam. Pria itu menggunakan kacamata, berpakaian formal berupa jas berwarna abu-abu dengan dalaman kemeja putih yang dan dihiasi dasi panjang berwarna navy blue. Pada tangan kiri pria itu memakai jam tangan dan sebuah cincin emas di jari manisnya. Tangan pria itu bersandar diatas meja yang terdapat beberapa gelas kaca, piring dan botol kayu. Ekspresi yang digambarkan pria itu terlihat kaget sambil berkata "Jesus Christ" dalam posisi kepala memandang kebawah mengarah handphone berwarna hitam yang dipegangnya. Pada gambar 23 terlihat sebuah tangan seseorang sedang menggenggam handpone berwarna hitam, pada layar handphone tersebut menunjukan $12.55 \mathrm{pm}$ atau jam 1 siang. Terlihat juga pesan yang di kirim oleh seseorang dengan nama "Unknown", isi pesan yang dikirim berupa sebuah foto pria dan wanita sedang berciuman di dalam restoran, dibawahnya terdapat pesan bertuliskan "I want the names" kedua pesan itu muncul pada waktu yang sama dengan handphone tersebut. Pengambilan gambar pada scene ini adalah Extreme Close $U p$ rangsangan seksual (Ramdani, 2015:119). Melihat Hennessy yang sedang berciuman dengan Maggie. Quan langsung menilai jika orang yang ditemui Henessy merupakan selingkuhannya.

\section{Analisis Gambar 22}

Ekspresi terkejut pada wajah Hennessy dapat terlihat melalui alis mata naik, mata terbuka lebar, dan mulut terbuka karena memperoleh sebuah pesan yang belum diketahui sebelumnya atau diluar dugaan. (Ramdani, 2015: 31), Ungkapan "Jesus Christ" yang Hennessy ucapkan merupakan spontanitas dari rasa terkejutnya.

\section{Analisis Gambar 23}

Dalam hal ini Hennessy langsung mengetahui jika pesan itu merupakan ancaman yang dikirim oleh Quan. Pesan tersebut merupakan kemarahannya dalam bentuk agresi tanpa tujuan menyakiti secara fisik. Kemarahan pada konteks ini merupakan kemarahan dengan intensitas ringan yaitu mengganggu perasaan orang lain (Aditya, 2015: 50). Pesan ancaman yang dikirimkan Quan bertujuan agar memberikan tekanan mental kepada Hennessy agar mau memberikan nama-nama teroris yang telah membunuh putrinya.

\section{Representasi kemarahan pada tabel 4} menggambarkan bahwa dalam melampiaskan kemarahannya, orang tidak selalu menyakiti targetnya secara fisik. Melalui komunikasi atau tindakansecara verbal pun orang dapat membuat targetnya menjadi tertekan. Dalam scene terlihat melalui pesan ancaman berisikan foto ciuman Hennessy dengan Maggie yang dikirim Quan melalui SMS (pesan singkat) dapat membuat Hennessy sosok yang memiliki kuasa tinggi dalam pemerintahan pun dapat menjadi takut dan merasa dirinya tidak aman karena terror dari Quan.

Tabel 5. Ancaman Bomb Kedua

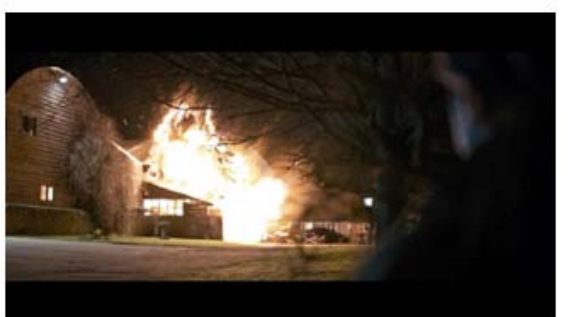

Gambar 24 Quan Mengebomb Lokasi Kediaman Hennessy

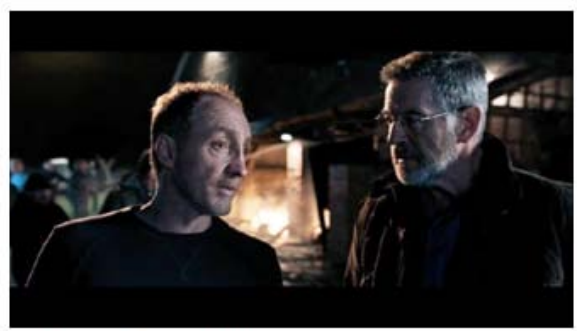

Gambar 25 Interaksi Hennessy Dengan Bawahannya
Pada gambar 24 menggunakan pengambilan Long Shot dengan pengambilan Long shot dapat terlihat setting lokasi di lingkungan perumahan di waktu malam hari. Dalam scene di atas terdapat tiga bangunan rumah dan satu mobil berwarna hitam yang sedang parkir di lingkungan itu, terlihat ledakan besar yang muncul dari salah satu rumah tersebut. Dengan sudut pandang Over shoulder view terlihat siluet pundak seseorang dibalik gelapnya pepohonan, pandangannya mengarah ke ledakan di rumah nomor kedua.

\section{Analisis Gambar 24}

Siluet orang itu sedang melihat ke arah ledakan pada rumah urutan kedua dalam scene. Tepat disebrang ledakan bomb itu terdapat sebuah rumah dan mobil sedang berwarna hitam terparkir disana. Rumah tersebut merupakan rumah milik Hennessy, sedangkan rumah yang diledakan merupakan gudang miliknya.Kemudian orang yang melakukan terror bomb itu adalah Quan, dia melakukan ancaman bomb kedua yang lebih ekstrim dibandingkan dengan ancaman bomb yang pertama. Ledakan bomb pertama berlokasi di toilet tempat kerja Hennessy dan radius bombnya hanya seluas ruang toilet itu saja. Sementara pada ancaman bomb yang kedua ini, ledakannya dapat menghancurkan satu rumah dan jika dilihat 
Pada gambar 25 terlihat dua pria yang terlihat tua sedang melakukanpembicaraan, pria di sebelah kiri memakai sweater berwarna hitam dengan posisi kepala menyerong ke arah pria disebelahnya. Sementara priakedua terlihat lebih tua dari si pria yang memakai sweater hitam, pria tersebut mengenakan kacamata dan jaket berwarna hitam. Pria yang mengenakan sweater hitam berkata kepada pria tua disebelahnya. lokasinya tepat berada di daerah kediaman pribadi Hennessy.

\section{Gambar 25}

Pada gambar 25 dengan pengambilan Medium Shot memperlihatkan hubungan personal antara Hennessy dan bawahannya, dibelakang mereka terlihat bekas ledakan dari rumah yang telah di bomb tadi. Hennessy dan anak buahnya mengenakan baju serba berwarna hitam. Warna hitam memiliki makna negatif takut, ketakutan, dan kematian (Nugroho, 2008:38). Mereka berdua terlihat berinteraksi membicarakan ledakan bomb yang barusan terjadi di lokasi itu.

Representasi kemarahan pada tabel 5, adalah mengebomb toilet tempat Hennessy bekerja, daya pengekspresian kemarahan secara Anger Out ledaknya tidak terlalu besar, hanya seluas ruang dimana orang mengekspresikan kemarahannya toilet saja. Namun dalam scene ini Quan menjadi dalam bentuk tindakan agresif dan merusak semakin agresif dengan mengebomb lokasi (Safaria dan Saputra, 2012: 85). Kemarahan Minh kediaman Hennessy, serta radius ledakan bombnya Quan menjadi lebih agresif dari sebelumnya, lebih besar dari sebelumnya.Tetap, aksinya tidak hal ini dapat dilihat melalui lokasi serta daya merenggut korban jiwa setelah kejadian itu. ledak bomb yang dia pasang. Sebelumnya Quan

Tabel 6. Ancaman Membunuh Minh Quan

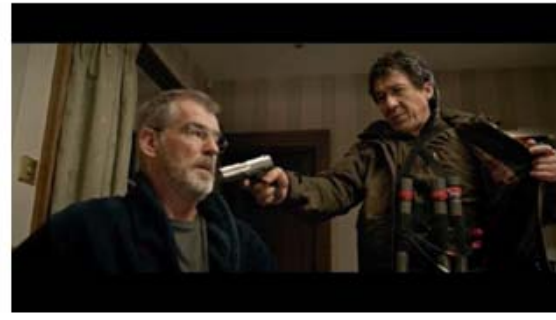

Gambar 26 Quan Mengancam Hennessy

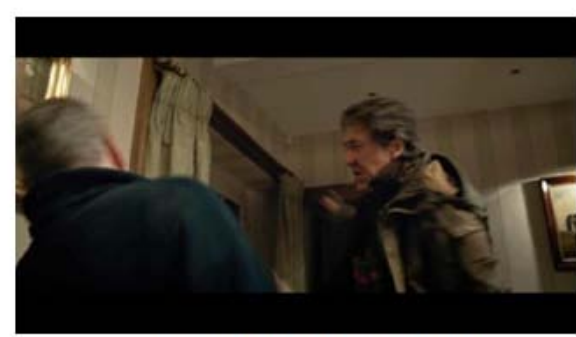

Gambar 27 Quan Memukul Hennessy

\begin{tabular}{ll}
\hline Object & \multicolumn{1}{c}{ Interpretant } \\
\hline Pada gambar 26 terlihat dua orang pria tua & Gambar 26 \\
sedang berada di dalam ruangan. Pria & Pada gambar 26 menggunakan pengambilan medium shot dengan \\
pertama berada di posisi berdiri, pria itu & sudut pandang low angle. Dengan sudut pandang low angle \\
mengenakan jaket dan kaos berwarna hijau & memperlihatkan posisi Quan yang lebih dominan atau berkuasa \\
tua, tangan kirinya erlihat sedang & dibanding Hennessy. Pada tangan kiri Quan memegang pistol \\
membuka jaket miliknya untuk & berjenis handgun yang diarahkan ke kepala Hennessy, sementara \\
menunjukan sebuah alat yang diikatkan di & tangan kanannya memegang tombol bomb sambil menunjukan \\
tubuhnya. Sementara tangan kanannya & bomb yang dipasang di sekujur ditubuhnya. \\
sedang memegang sebuah pistol yang di & \\
arahkan ke kepala pria yang berada di & Gambar 27 \\
posisi lebih rendah darinya, pria itu terlihat & Pada gambar 27terlihat gerakan Quan sedang memukul wajah \\
sedang duduk dengan pandangan lurus & Hennessy dengan pistol. Pada scene tersebut Quan membahas \\
kedepan. Pria yang sedang duduk itu & mengenai bahan bomb yang digunakan oleh teroris IRA dalam \\
mengenakan sweater berwarna biru dan & melakukan aksi pengebombannya, Quan mengetahui bahan yang \\
kaos abuabu. Terjadi percakapan yang & digunakan oleh teroris itu adalah Semtex H, Peneliti menelusuri \\
dilakukan antara mereka. Pengambilan & bomb ini melalui situs explozia.cz ada beberapa jenis bomb bertipe \\
gambar Medium Shot dengan sudut & Semtex dan salah satunya adalah Semtex H, bomb ini merupakan \\
pandang low angle & jenis bahan peledak berbahan plastic dengan komponen zat warna \\
Pada gambar 27 pria berpakaian hijau & sebagai alat deteksi pra ledakan. Quan merasa hal tersebut \\
memukul wajah pria bersweater biru & sangatlah ironis, karena dulu saat perang Vietnam, dia \\
dengan gagang pistol yang berada di & menggunakan bomb berjenis Semtex H untuk membunuh tentara \\
tangan kanannya sambil berkata berkata & Amerika. Kini justru anak perempuannya yang terbunuh oleh IRA \\
'We are nothing a like, you are killing & menggunakan bomb tersebut. \\
woman and children. Names!" &
\end{tabular}


Dapat disimpulkan tahap kemarahan pada tabel 6 yaitu, kemarahan pada diri Minh Quan kepada Hennessy telah mencapai batasnya. Awalnya dia sangat menghindari kekerasan fisik langsung ke Hennesy. Namun, karena seluruh ancaman yang diberikan sebelumnya tidak memberikan efek jera pada Hennessy agar memberikan nama pengebomb tersebut. Akhirnya dia melakukan agresi emosional berupa ancaman membunuh kepada Henessy.

Tabel 7. Empati Minh Quan

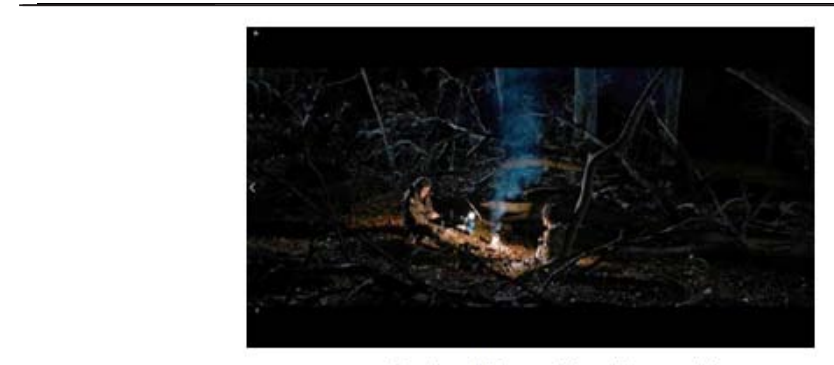

Gambar 28 Quan Menginterogasi Sean

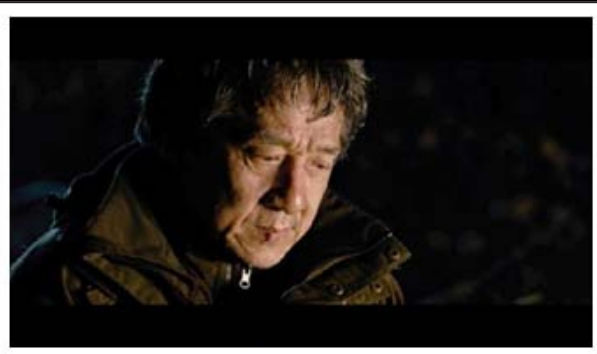

Gambar 29 Ekspresi Empati Quan

\begin{tabular}{l} 
Object \\
\hline Pada gambar 28 diambil dengan pengambilan gambar \\
Long Shot, dengan pengambilan gambar tersebut \\
terlihat suasana pada malam hari di tengah hutan, \\
disana terlihat dua orang sedang duduk dengan jarak \\
yang berjauhan, jarak mereka dibatasi dengan api \\
unggun yang berada di tengah mereka
\end{tabular}

Pada gambar 28 terlihat pria berambut yang berada di arah sebelah kiri pada scene sedang duduk menghadap kearah handphone yang berada di tangannya. Di samping pria sedang memegang handphone terlihat beberapa peralatan kemah berwarna biru. Sementara pria yang satunya lagi memiliki rambut yang agak panjang kira-kira se-leher sedang duduk bersandar pada batang pohon dengan posisi kedua tangan terikat di belakang serta kaki yang terikat Pria berambut pendek itu berkata "Do you know why you are stil alive?" Pria berambut panjang menjawab "You want the names? It's on the phone. Five names and location in London." Pria berambut pendek menanyakan kembali "You have family?" Pria berambut panjang mejawab "A brother, the rest has passed away."

Gambar 29 memperlihatkan ekspresi atau respon pria berambut pendek setelah mendengar lawan bicaranya memberi tahu tentang sisa keluarga yang dimilikinya

\section{Analisis Gambar 28}

Interpretant

Pada gambar 28 menggunakan pengambilan Long Shot, yang memperlihatkan suasana pada malam hari di tengah hutan hanya di terangi oleh cahaya dari api unggun.

Dalam scene terlihat dua orang pria sebelah kiri pada gambar adalah Quan sementara di sebelah kanan pria yang berada di dalam kondisi terikat adalah Sean keponakan dari Hennessy. Sebelumnya Quan dan Sean sempat terlibat perkelahian, Sean ditugaskan oleh Henessy untuk membunuh Quan, namun usahanya gagal dan justru, menjadi tahanan Quan.

\section{Analisis Gambar 29}

Empati adalah merasakan yang dirasakan orang lain, atau mampu memahami perspektif orang lain (Ramdani, 2015: 96). Dalam menunjukan rasa empatinya, Quan menundukan kepala dan pandangan matanya kearah kiri bawah. Jika seseorang melihat ke bawah kiri, mereka membayangkan bagaimana perasaannya terhadap suatu hal (Eskawati, 2015: 174). Ini mengartikan, ketika Quan mendengar kondisi keluarga Sean, dia memposisikan dirinya sebagai saudara laki-lakinya. Jika dia membunuh Sean, dia memikirkan bagaimana perasaan saudara laki-lakinya ketika mengetahui Sean telah terbunuh. Quan tidak ingin hal yang terjadi pada dirinya juga terjadi pada saudara laki-laki Sean.

Kesimpulan tahap kemarahan pada tabel 7 adalah, Sebelumnya Quan bertindak sangat agresif dalam melampiaskan kemarahannya kepada Hennessy. Namun, sebesar apapun kemarahan yang dirasakan seseorang, ketika orang itu menaruh empati kepada orang lain yang nyaris bernasib sama dengannya, kemarahan pada dirinya akan redup. Dalam scene membuktikan hal tersebut, meskipun Quan mengetahui Sean ingin membunuhnya. Tetapi karena rasa empatinya terhadap Sean dan saudara laki-lakinya. Quan membiarkannya hidup, dia tidak ingin kejadian yang dialaminya terjadi juga pada orang lain. Pada tabel ini, memperlihatkan Quan yang berhasil menemukan kelima teroris yang bersangkutan dengan aksi bomb yang merenggut nyawa Fan. Berikut kelima nama teroris yang dibunuh oleh Quan: Mc Cormic, Pat Nuggent, Sarra McKay, Dennis Fisher, dan terakhir O'Reily merupakan pelaku yang telah membunuh Fan. 
Tabel 8. Minh Quan Membunuh Kelima Teroris

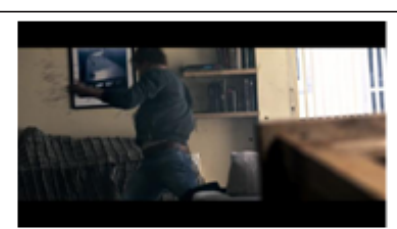

Gambar 30 Quan Menembak Mo Cormic

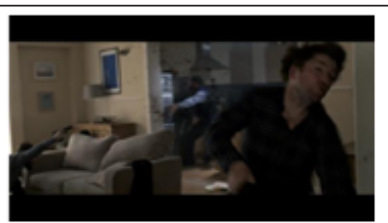

Gambar 31 Quan Menembak Dennis Fisher

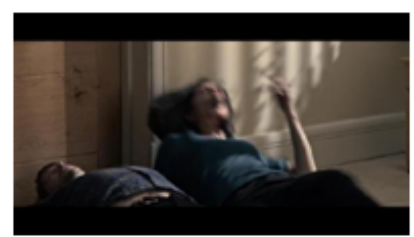

Gambar 32 Quan Menembak Sarra McKay

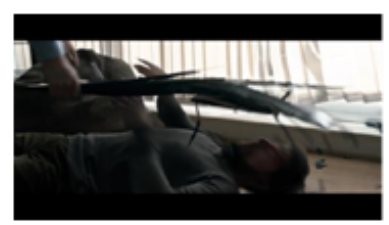

Gambar 33 Quan Memukul Pat Nuggent dengan Televisi

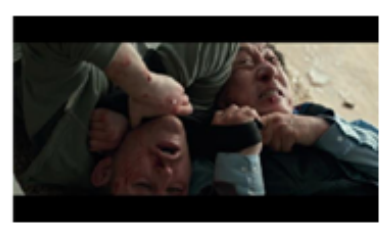

Gambar 34 Quan Menyekik OReily dengan kain

\section{Object}

\section{Interpretant}

Pada gambar 30 terlihat seorang pria mengenakan sweater berwarna biru sedang memalingkan tubuhnya seperti terhantam sesuatu, terdapat bercak darah yang membekas di tembok berwarna kuning tepat di belakang pria itu, sudut pengambilan gambar dari arah meja kayu yang terlihat lebih dekat pada scene

Pada gambar 31 terlihat seorang pria mengenakan kemeja gelap dengan garis kuning terkena tembakan dari orang memakai pakaian lengan panjang berwarna biru muda di belakangnya, bercak darah memuncrat dari tubuh si pria yang memakai kemeja berwarna biru. Sementara di belakangnya terjadi baku tembak antara pria yang berada di sofa putih yang memegang sebuah pistol dengan pria memakai baju berwarna biru muda.

Pada gambar 32 terlihat seorang wanita memakai baju berwarna biru tua dan celana hitam sedang berbaring di lantai bersama seorang pria memakai kemeja berwarna hitam dengan garis kuning. Wanita itu berteriak "akkhh" dengan darah yang menyiprat pada tembok kayu yang berada di belakangnya.

Pada gambar 33 terlihat seorang pria memakai sweater berwarna abu-abu dalam posisi terbaring di lantai, pria dipukul menggunakan sebuah benda oleh seseorang. Hal ini dapat dilihat melalui adanya tangan seseorang dengan pakaian lengan panjang memukul kepala pria yang sedang terbaring tersebut menggunakan televisi LED.

Pada gambar 34 menggunakan teknik pengambilan Close Up, dengan pengambilan tersebut dapat terlihat dua orang pria sedang berbaring di lantai. Pria memakai baju biru muda dengan wajah terluka pada bibir dan pelipisnya menunjukan ekspresi marah dengan posisi kedua tangannya menyekik pria berpakaian hijau tua menggunakan kain hitam. Pria yang memakai baju berwarna hijau tersebut terlihat berusaha melepaskan ikatan kain yang menjerat lehernya, wajah dan tangannya terlihat penuh luka bersimba darah. Ekspresi yang ditunjukan terlihat menganga seperti kehabisan nafas karena di cekik pria disampingnya.

\section{Analisis Keseluruhan Gambar}

Tindakan yang dilakukan Quan pada tabel ini merupakan bentuk amarahnya atas kematian Fan. Amarah yang dimaksud adalah pengungkapan secara Anger Out yaitu reaksi individumengekspresikan emosinya dalam bentuk merusak, dan melakukan tindak agresif (Safaria dan Saputra 2012:85). Amarah ini merujuk pada perasaan seseorang akibat disakiti oleh orang lain, hal itu dapat memotivasi orang yang tersakiti untuk melakukan tindak agresi. Tindak agresi yang Quan lakukan adalah Agresi Instrumental. Menurut Berkowitz, tindakan ini dilakukan untuk tujuan ekstrinsik, jadi pelaku agresif ini memiliki tujuan lain disamping kejahatan (Berkowitz, 2006:15). Orang yang memiliki agresivitas tinggi ini disertai dengan kemarahan ketika melakukan tindak agresinya.

Jika diperhatikan sebelumnya, Quan tidak melakukan pembunuhan sama sekali dalam melampiaskan kemarahannya pada Hennessy untuk mendapatkan nama-nama teroris itu. Hal ini disebabkan karena Hennessy tidak secara langsung terlibat atas kematian putrinya, sedangkan pelampiasan kemarahan Quan dengan membunuh teroris bertujuan untuk membalas kematian putrinya karena perbuatan mereka. 
Kesimpulan tahap kemarahan pada tabel 8 adalah seseorang akan melampiaskan kemarahan mereka pada orang yang telah menyakitinya. Kemarahan yang tidak dapat dikontrol dengan baik akan memotivasi orang tersebut dalam melakukan tindakan agresi yang merusak hingga membunuh. Dalam scene, satu-satunya yang ada di benak
Quan agar dapat terbebas dari kemarahannya yaitu dengan memburu lalu membunuh pelaku yang telah membunuh Fan. Dalam benak hatinya, kematian Fan harus dibayar dengan nyawa pelaku tersebut. Setelah tujuannya tercapai, barulah dia merasa terbebas dari kemarahannya karena telah membalaskan kematian putrinya.

Tabel 9. Penyelesaian Akhir Quan Dengan Hennessy

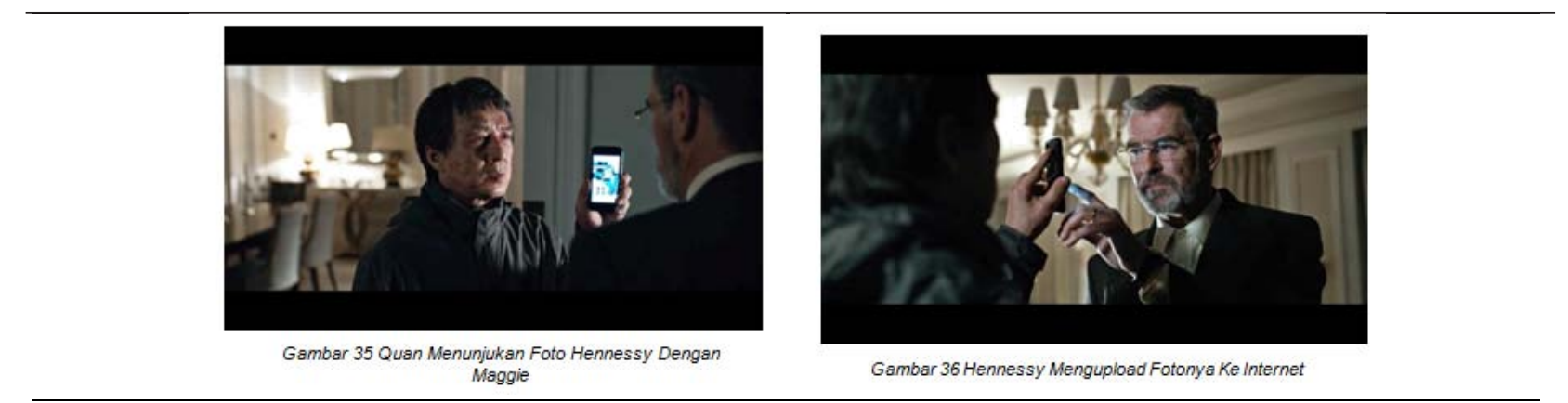

\begin{tabular}{l}
\hline Object \\
\hline Pada gambar 35 Terlihat seorang pria tua \\
memakai jaket berwarna abu-abu gelap. Ekspresi \\
yang digambarkan oleh pria tersebut terlihat \\
sedang marah dengan lawan bicaranya. Di \\
genggaman tangan kiri yang di angkat oleh pria \\
itu menunjukan sebuah handphone berwarna \\
hitam dengan layar bergambarkan seorang pria \\
sedang berciuman dengan wanita yang di arahkan \\
ke wajah lawan bicaranya. \\
Di gambar 36 terlihat seorang pria tua memakai \\
kacamata, berpakaian kemeja putih dan dilapisi \\
jas hitam sedang melakukan interaksi dengan pria \\
yang berada di hadapannya. \\
Ekspresi yang digambarkan oleh pria tua setelah \\
itu terlihat ketakutan ketika memandang kearah \\
layar handphone yang ditunjukan oleh pria yang \\
berada di hadapannya, tangan kiri pria itu terlihat \\
menyentuh layar handphone yang dimiliki oleh \\
lawan bicaranya. \\
Pengambilan gambar pada kedua gambar diatas \\
adalah Medium Shot, dengan sudut pandang Over \\
Shoulder Shot.
\end{tabular}

\section{Gambar 35}

Interpretant

Pada gambar 35 terlihat sosok Quan dari arah bahu lawan mainnya yaitu Hennessy, dalam scene Quan dan Hennessy memakai pakaian serba berwarna abu-abu yang memiliki makna keseimbangan, kebijakan, dan emosi kuat (Nugroho, 2008: 38). Hal tersebut memaknai kesetaraan diantara mereka berdua.

Berbeda dengan pertemuan sebelumnya dengan Hennessy, pada scene ini dia tidak terlihat membawa benda-benda yang dapat mengancam nyawa Hennessy. Wajah yang diperlihatkan Quan terlihat marah sambil menunjukan handphone pada tangan kanannya ke wajah Hennessy, dalam layar handphone tersebut terlihat foto aib Henessy bersama selingkuhannya Maggie.

\section{Gambar 36}

Pada gambar 36 pengambilan Over Shoulder Shot dari arah bahu Quan terlihat reaksi Hennessy. Dia menggelengkan kepalanya setelah Quan memberi kesimpulan seperti itu. Gelengan kepala menandakan penolakan atau ketidak setujuan dari apa yang disampaikan (Ramdani, 2015:34).
Dapat disimpulkan representasi kemarahan pada tabel 9 memperlihatkan kemarahan pada diri seseorang dipicu karena merasa dibohongi oleh orang lain. Orang tidak harus melampiaskan kemarahannya dengan tindakan agresi secara fisik. Kemarahan yang dilampiaskan dengan menyerang secara mental dapat memberikan tekanan yang besar dalam diri orang lain yang memicu kemarahan kita. Dalam scene Quan merasa dirinya telah dibohongi sejak awal oleh Hennessy, dia tidak lagi melakukan agresi secara fisik terhadap Hennessy melainkan melakukan agresi yang menyerang mentalnya. Dengan memaksa Hennessy untuk mengirim foto aibnya bersama teroris ke internet. Hal itu akan memberikan tekanan mental yang besar dalam hidupnya yaitu kehilangan kehormatan, serta karirnya.

Kesimpulan bahwa kemarahan dapat membuat semua orang lupa akan dirinya. Kemarahan juga direspon secara berbeda oleh setiap individu. Pada 
kasus tokoh Quan, kemarahan yang ada di dalam dirinya baru akan hilang ketika kemarahan tersebut dapat terlampiaskan atau terbalaskan pada orang yang bersangkutan. Kemarahannya terlampiaskan dengan cara membunuh pelaku bomb yang telah menewaskan putrinya. Setelah terlampiaskan barulah akan tenang hati dan jiwanya. Ketika Quan kembali dan bertemu dengan Lam dia tidak bisa berkata apa-apa, tangisannya memilik makna jika dia menyadari apa yang dia lakukan sebelumnya adalah sebuah kesalahan. Ketika Lam memeluknya, Quan baru menyadari jika dia masih memiliki orang yang benar-benar khawatir dan mencintainya dengan setulus hati.

Peneliti menemukan bahwa tahapan kemarahan yang di bangun pada tokoh Minh Quan berdasarkan atas realitas sosial yang ada. Teori Konstruksi Realitas Sosial ditemukan oleh Berger dan Luckmann, teori ini dibagi menjadi tiga proses diantaranya: Eksternalisasi, Objektivasi, Internalisasi. Kreator film The Foreigner menciptakan bentuk kemarahan berdasarkan frame of reference dan field of experience. Berikut penjabaran ketiga proses yang di konstruksi pada tokoh Minh Quan dalam film The Foreinger.

Eksternalisasi. Eksternalisasi adalah usaha pencurahan atau ekspresi diri manusia ke dalam dunia, baik dalam kegiatan mental maupun fisik. Pada proses ini, kreator film ingin menyampaikan pesan mengenai realitas kemarahan pada seseorang melalui sebuah film. Kreator film melakukan riset terhadap novel bergenre thriller The Chinaman (1992) Karya Stephen Leather dan mengangkatnya menjadifilm The Foreigner (2017). Riset yang dilakukan oleh kreator film termasuk kedalam frame of reference sedangkan field of experience didapatkan melalui pengalaman kreator film dalam melihat realitas kemarahan yang ada di kehidupan nyata.

Objektivasi. Objektivasi dapat terjadi melalui penyebaran opini sebuah produk sosialyang berkembang di masyarakat melalui diskursus opini masyarakat tentangproduk sosial, dan tanpa harus terjadi tatap muka antar-individu dan penciptaproduk sosial itu.Proses Objektivasi ini adalah proses dimana kreator film menjadikan film The Foreigner sebagai produk sosial dalam membanguun opini tentang kemarahan pada tokoh Minh Quan menjadi suatu kebenaran berdasarkan refleksi kemarahan manusia di realitas. Kemarahan muncul karena memiliki penyebab, kemarahan semakin tumbuh karena perasaan bersalah dan depresi yang terlalu lama, manusia akan melakukan hal apapun dalam melampiaskan kemarahannya kepada orang yang telah menyakitinya, kemarahan yang tidak terkontrol dengan baik akan memotivasi orang dalam melakukan tindakan agresi contohnya: membunuh, ketika kemarahan tersebut terlampiaskan barulah manusia tersebut akan merasa tenang hatinya.

Internalisasi. Proses internalisasi adalah peresapan kembali realitas tersebut olehmanusia dan mentransformasikannya lagi dari strukturstruktur dunia objektif ke dalam struktur-struktur kesadaran subjektif. Dalam proses internalisasi, kreator film menggambarkan tahapan kemarahan yang di visualisasiskan pada tokoh Minh Quan yangdisajikan menjadi scene/adegan dalam film The Foreigner. Yang berarti, proses ini adalah bagaimana audiens atau masyarakat yang menyaksikan film The Foreigner dapat mencerna pesan kemarahan yang divisualisasikan oleh tokoh Minh Quan.

\section{SIMPULAN}

Melalui penelitian ini, dengan menggunakan teori Konstruksi Realitas, serta menggunakan semiotika Triangle Meaning oleh Charles Sanders Peirce sebagai metode dan analisisnya, peneliti menemukan bahwa kemarahan seseorang muncul karena adanya alasan atau penyebab tertentu dan jika tidak terkontrol dengan baik akan berakhir dengan tindakan agresi, yaitu membunuh.

Berdasarkan hasil analisis triangle meaning semiotics yang dikemukakan oleh Charles Sanders Peirce yaitu sign, object, interpretant di atas, peneliti menemukan representasi kemarahan yang dikonstruksi pada tokoh Minh Quan yaitu: (1) Kemarahan timbul karena perbuatan buruk yang orang lain lakukan terhadap diri kita150; (2) Pada awalnya orang akan merenungkan isi hatinya dalam memendam apa yang menjadi penyebab kemarahannya; (3) Kemarahan juga dipicu ketika seseorang merasa disepelekan oleh orang yang diharapkan dapat membantunya 
untuk menghilangkan kemarahan itu; (4) Kondisi stress,dan depresi karena terlalu berlarut-larut dalam memendam hal yang membuat kita menjadi marah, akan memicu kemarahan tersebut tumbuh semakin kuat; (5) Orang akan menggunakan segala cara untuk melampiaskan kemarahannya kepada orang yang telah menyakitinya; (6) Kemarahan tersebut hanya dilampiaskan kepada orang yang menimbulkan kemarahan pada diri kita; (7) Kemarahan yang tidak dapat terbendung lagi, akan menimbulkan tindak agresi fisik atau psikis terhadap orang yang memicu kemarahan kita; (8) Sebesar apapun kemarahan yang dirasakanseseorang, ketika dia berempati terhadap orang yang bernasib sama dengan dirinya, hal tersebut dapat meredam kemarahan yang dia rasakan; (9) Kemarahan yang tidak terkendaliakan memotivasi seseorang untuk melakukan tindakan agresi yang ekstrim yaitu membunuh; (10) Setelah kemarahan yang membebani dirinya dapat terlampiaskan barulah orang tersebut akan merasa tenang hatinya.

Berdasarkan seluruh hasil penelitian, peneliti memberikan saran kepada peneliti berikutnya yang tertarik untuk mengangkat topik tentang kemarahan pada film agar menggunakan teori lainnya. Contohnya: Komodifikasi, Analisis Resepsi, Budaya Populer, dan lainnya, agar dapat memperkaya studi tentang kemarahan dalam bidang komunikasi, khususnya analisis semiotika. Peneliti juga memberikan saran kepada kreator film agar dalam mengonstruksi realitas kemarahan tidak harus selalu berakhir dengan cara kekerasan seperti di film The Foreigner, hal tersebut perlu dilakukan agar para penikmat film atau audiensnya dapat mengambil nilai kehidupan jika kemarahan yang terkelola dengan baik dapat diselesaikan secara baik-baik

\section{DAFTAR PUSTAKA}

Aditya, C. (2015). Berbagai Terapi Jitu Atasi Emosi Sehari-hari. Yogyakarta: FlashBooks.

Amda, K., \& Fitriyani, R. (2016). Membaca Ekspresi Wajah Mengungkap Kepribadian Seseorang Dengan Membaca Wajah. Depok: Huta.

Berger, A. A. (2012). Media and Society: A Critical Perspective. Retrieved Agustus 2018, from
Google Books.

Berkowitz, L. (2006). Emotional Behavior: Mengenali Perilaku dan Tindak Kekerasan di Lingkungan Sekitar Kita dan Cara Penanggulangannya. Jakarta Pusat: PPM, anggota Ikapi.

Box Office Mojo, (2017, October 13). The Foreigner (2017), Retrieved November. 12, 2018, from: https://www.boxofficemojo. $\mathrm{com} / \mathrm{movies} /$ ?id=theforeigner.htm

Bungin, B. (2008). Konstruksi Sosial Media Massa: (Kekuatan Pengaruh Media Massa, Iklan Televisi, Dan Keputusan Konsumen Serta Kritik TerhadapPeter L. Berger \& Thomas Luckmann), Cetakan pertama. Jakarta: Kencana.

Bungin, B.(2013). Sosiologi Komunikasi Teori Paradigma, dan Diskursus Teknologi Komunikasi di Masyarakat. Jakarta: Kencana.

Cangara, H. (2016). Pengantar Ilmu Komunikasi. Jakarta: PT. Rajagrafindo Persada.

Diniati, A \& Pratiwi. (2017). Analisis Semiotika Citra Polisi dalam Film Pendek Joni Sok Jagoan Di Youtube. Wacana: Jurnal Ilmiah Ilmu Komunikasi, 17(1), 91-104.

Eskawati, D. (2015). Pintar Membaca Watak \& Pikiran Orang Lain (cukup satu kedipan). Yogyakarta: Notebook.

Fachruddin, A. (2012). Dasar-dasar Produksi Televisi: Produksi Berita, Feature, Laporan Investigasi, Dokumenter, dan Teknik Editing. Jakarta: Kencana.

Hanani, S. (2017). Komunikasi Antarpribadi Teori dan Praktik. Yogyakarta: AR RUZZ MEDIA.

IMDb. (2017, October 13). The Foreigner (2017). Retrieved November 12, 2018, from: https://www.imdb.com/title/tt1615160/ fullcredits? $\mathrm{ref}=\mathrm{ttql1}$

IMDb. (n.d.).The Foreigner (2017). Retrieved November 12, 2018, from:https:// www.imdb.com/title/tt $1615160 /$ plotsummary?ref=ttqlstry3syn opsis. 
Karima, S., \& Christin, M. (2015). Analisis Semiotika Charles Sanders Peirce atas Presentasi Kekerasan dalam Serial Film Kartun Little Krishna Episode 5 September 2014. e-Proceeding of Management, 2237 $-2243$.

KBBI. (n.d). Pengertian Uang. Retrieved December 30, 2018, from https://kbbi.web.id/uang

KBBI. (n.d). Pengertian Marah. Retrieved December 30, 2018, from https://kbbi.web. id/marah

Lubis, N. L. (2009). Depresi: Tinjauan Psikologis. Jakarta: Kencana Prenada Media Group.

Mulyana, D. (2014). Ilmu Komunikasi Suatu Pengantar. Bandung: Remaja Rosdakarya.

Nugroho, E. (2008). Pengenalan Teori Warna. Yogyakarta: Andi Offset.

Prawitasari, J. E. (1995). Mengenal Emosi Melalui Komunikasi Non Verbal. Buletin Psikologi, 27-40.

Ramdani, Z. P. (2015). Gesture Mengungkap Makna Dibalik Bahasa Tubuh Orang Lain Dari Mikroekspresi Hingga Makroekspresi. Klaten: PT. HAFAMIRA.

Safaria, T., \& Saputra, N. E. (2012). Manajemen
Emosi (Sebuah Panduan Cerdas Bagaimana Mengelola Emosi Positif Dalam Hidup Anda). Jakarta: PT. Bumi Aksara.

Susanto, E. (2018). Pintar Mengenali Bahasa Wajah dan Tubuh Orang. Yogyakarta: Laksana.

Sobur, A. (2009). Semiotika Komunikasi. Bandung: PT. Remaja Rosdakarya.

Sobur, A. (2015). Analisis Teks Media: Suatu Pengantar Untuk Analisis Wacana, Analisis Semiotik, dan Analisis Framing. Bandung: Remaja Rosdakarya.

Toni, A., \& Rafki. (2017). Studi Semitoka Pierce pada Film Dokumenter 'The Look of Silence: Senyap'. Jurnal komunikasi, 11(2), April 2017.

Vera, N. (2014). Semiotika Dalam Riset Komunikasi. Bogor: Ghalia Indonesia.

Vidrayani, T. N. (2007). Representasi Kecantikan Dalam Iklan Kosmetik The Face Shop. Jurnal Ilmiah SCRIPTURA, 83-97.

Wibisono. (2018). Satu Menit Baca Bahasa Tubuh Orang Lain. Yogyakarta: Checklist.

Wisnuwardhani, Dian S. F. (2012). Hubungan Interpersonal. Jakarta: Salemba Humanika. 